\title{
A HISTOCHEMICAL STUDY OF DPN-DIAPHORASE IN HUMAN WHITE MATTER WITH SOME NOTES ON MYELINATION
}

\author{
Reinhard L. Friede \\ Mental Health Research Institute and Laboratory of Neuropathology, \\ University of Michigan, Ann Arbor, Michigan, U.S.A.
}

(Received 12 January 1961)

THERE is some indication of differences in the anatomical and chemical organization of individual fibre tracts in the brain, such as the outstanding activity of alkaline phosphatase in the retroflex bundle of the guinea pig (SHImIzU, 1950) and the different rates of synthesis of acetylcholine in various fibre tracts (FELDBERG and VoGT, 1948).

This paper reports on the distribution of DPN-diaphorase in human white matter. The distribution of enzyme activity in human grey matter will not be touched upon. It resembles, in principle, that of succinic dehydrogenase in the guinea pig brain which, in turn, is similar to that of several oxidative enzymes in cat brain as documented recently in an histochemical atlas (FRIEDE, 1961). The activity of oxidative enzymes is much less in white matter than in grey matter, as shown by both biochemical and histochemical data. Histochemical studies revealed detailed differences in the cytological enzyme distribution in the various tracts. Some data on myelination and on certain features of enzyme transport in axons were included in this study because they imply a difference in the chemical organization of the tracts.

\section{MATERIAL AND METHODS}

Histochemical techniques. DPN-diaphorase was demonstrated with the histochemical techniques of Farber, Sternberg and Dunlap (1956) and of Scarpeldi, Hess and Pearse (1958) with equally satisfactory results. Large series were available from six human brains without pathological changes. Brains could te used up to $10 \mathrm{hr}$ after death with perfect histochemical results. The tissue was fixed in formalin (SAMORAJSKI, 1960); identical results were obtained in sections from fresh frozen tissue and from formalin-fixed tissue. Contrary to Samorajski's observations, an initial increase in enzyme activity was not observed following exposure to formalin; instead the enzyme activity decreased gradually. For fixation, the tissue had to be cut in $5-8 \mathrm{~mm}$ slices. In thicker specimens fixation did not extend to the centre of the block which was still pink after one day and yielded a somewhat stronger reaction. The decrease in enzyme activity was greatly delayed by immediate cooling of the tissue in a refrigerator following exposure to formalin; there was little loss in activity during the first 2-3 days. This facilitated handling of much larger series than was possible with fresh frozen sections. Fair results were obtained with tissue stored for 5 days in the refrigerator. After 5 days there was a considerable weakening of the reaction. Temporary removal of the tissue from the refrigerator also weakened the reaction. Fixation in CAJAL's (1928) brom-formalin, as used for glia impregnations. completely destroyed enzyme activity. Sections were cut at $30 \mu$, washed in distilled water, and ir cubated in a Technicon water bath at $38^{\circ}$ for $2 \mathrm{hr}$ in either of the above media. The volume of incubation medium was adjusted according to the number and size of sections as too much tissue decreased the general staining intensity. About $15 \mathrm{ml}$ of fluid for 10 large sections $(20 \times 20 \mathrm{~mm})$ taken from a region with strong enzyme activity, was a satisfactory proportion. After completion of the reaction, one half of the material was dehydrated and mounted in balsam and the rest in glyceringelatin. Mounting in balsam improved the discernibility of cellular details in white matter. The 
findings were controlled by comparison with sections mounted in glycerin-gelatin (PEARSE, 1960). Some sections were routinely counterstained with chromalum-gallocyanin to obtain sharper cytological localization.

Cell counts. During the cutting of tissue for the enzyme reaction, alternate sections were saved for cell counts; they were stained by chromalum-gallocyanin, dehydrated, and mounted in balsam. These sections represented a $30 \mu$ layer of tissue regardless of the shrinkage of the thickness during dehydration. The shrinkage in width was determined by comparison with sections from the same block which were mounted directly in glycerin-gelatin without dehydration. Dehydrated sections were mounted individually and the extent of the shrinkage varied in the range of 5-10 per cent. This shrinkage and its variation have to be taken into consideration when the present data are compared with data on fresh tissue. Volume changes due to fixation in formalin were neglected. The numbers of glial cells in fibre systems were counted with an ocular-net micrometer with 100 squares. All counts were made by the same person. Endothelial cells and the glial septa between the fibre bundles in the brain stem were excluded; the use of thick sections facilitated the identification of endothelial cells since the sections always contained larger segments of the vessels. No differential counts of the types of glial cells (astrocytes, oligodendroglia, microglia, etc.) were made. The above technique was also used to count cells with enzyme activity. At least 20 counts were made for each of the values reported in the text; the data were subjected to statistical analysis.

Densitometric measurements of myelin. Sections were cut from formalin fixed tissue at $30 \mu$; they were stained for a carefully standardized time in the same batch of Sudan black during one working period. The sections were washed in water so that no stain was dissolved from the tissue as by differentiation in alcohol. Measurements were made on a microscopic screen with a Welch Densichron densitometer. The densitometer readings were calibrated as follows: unstained tissue or tissue subjected to lipid extraction was considered to have a density of zero and stained tissue of normal white matter was arbitrarily chosen to be 100 .

\section{RESULTS}

\section{Distribution of DPN-diaphorase in human white matter}

A survey of the distribution of DPN-diaphorase activity in the various parts of white matter revealed considerable variations in the number of glial cells with enzyme activity and the intensity of the reaction in them. Enzyme activity was also found in axons. Since the myelin sheaths lacked enzyme activity, the axons were readily discernible within the surrounding tissue. The following terms were defined to describe enzyme activity in axons:

A prominent reaction showed a continuous, heavy staining of the axon and a very clear-cut separation of the axon from the adjacent tissue; the sharpness of the reaction resembled silver impregnations.

A distinct reaction permitted identification of axons but the staining intensity was either not very heavy or not entirely continuous throughout the length of the fibre.

A rague reaction showed weak activity in axons, which was, at times, difficult to distinguish from surrounding tissue.

A diffuse reaction showed a homogeneous distribution of formazan crystals in the tissue and localization in axons was not possible. It was felt that the diffuse reaction was localized, at least in part, in processes of glial cells. This was suggested by certain patterns which simulated the arrangement of glial processes, but no definite evidence for this localization was obtained. A 'diffuse' reaction was always associated with large numbers of oligodendroglia.

A quantitative estimate of the enzyme activity in glial cells was made by counting, in sections which were not counterstained, all glial perikarya which could be discerned by a positive reaction. Glial cells indiscernible because of negative reaction were 
represented by the difference between the number of perikarya with enzyme reaction and the total number of cells. Both series of counts were done simultaneously under the same conditions on material from the same subjects. In addition, an effort was made to describe the intensity of the reaction in the individual perikarya with the terms weak, medium or strong. One would expect that the number of cells discernible by a positive reaction would depend largely on the general intensity of the reaction but in practice variations in staining intensity had relatively little effect on the counts. The difference between cells with enzyme activity and cells with very little or none, was of sufficient magnitude to establish a histochemical gradient. The intensity of the reaction did not influence its pattern of distribution in axons or glial cells. If the reaction was too weak, both were barely discernible; a stronger reaction improved the contrast without change in the pattern. The material used for this investigation showed equal staining intensity throughout. The data (Table 1) show an inverse relationship between the reaction in axons and the number of glial cells with enzyme activity.

There were striking variations in the numbers of glial cells in the various fibre systems (Table 1), while the number in any tract was relatively constant as shown by counts at various levels of the same tract (pyramidal tracts, No. 18, 19, 20, 24); brachium conjunctivum (No. 21, 22); frontopontine tracts (No. 31, 32). Spot checks made at many levels of other fibre systems gave similar results.

A sizeable portion of the glial cell population contained enzyme activity but there was always another portion with extremely little or no enzyme activity. Most intriguing was the inverse relationship between the enzyme reaction in axons and the number of glial cells with enzyme reaction. Fibre tracts with strong activity in the axons contained few glial cells with enzyme activity (and had a low total glial count); on the other hand, fibre tracts showing no enzyme activity in axons contained many glial cells with enzyme activity (Figs. 1-8).

These patterns were to some extent related to the thickness of the fibres, since only thicker fibres had a 'prominent' reaction. The strong reaction in thick fibres probably resulted from the greater amount of axoplasm in them; one thick (A-) fibre contains as much axoplasm as 28 thin (C-) fibres (diameters taken from LLoyD and Chang, 1948). A thick axon, therefore, provides for the fibre a much better supply of axoplasm and with it enzyme activity than a thin axon. From these findings it was concluded that both axon and glial cells share the total enzyme activity required for the maintenance of a fibre, but the distribution between axon and glial cells varied in the individual tracts. The availability of axoplasm apparently was one of the factors determining this variance.

Some particular findings emphasized the correlation of axonal and glial enzyme supply as against the assumption that there was merely a relation between the number of glial cells and the number of fibres. The ventral spinal roots (Fig. 1) contained only a negligible number of glial cells with enzyme activity-too few to be of metabolic significance-while all the fibres showed a prominent reaction. These fibres thus had almost exclusively 'axonal' enzyme supply, regardless of the total number of glial cells available. In the frontal pole (Fig. 8), on the other hand, most of the enzyme activity available was definitely within glial perikarya, even if all of the 'diffuse' reaction was attributed to axons, which was unlikely. Goll's tract (Fig. 2) had relatively high total glial counts; however, only a few cells showed enzyme activity, while all the axons 
TABLE 1.-SURVEY OF SOME human CENTRAL TRACTS

\begin{tabular}{|c|c|c|c|c|c|}
\hline No. & Tract & $\begin{array}{c}\text { Cells with } \\
\text { enzyme } \\
\text { activity }\end{array}$ & $\begin{array}{l}\text { Total } \\
\text { glia } \\
\text { cells }\end{array}$ & $\begin{array}{l}\text { Reaction } \\
\text { in axons }\end{array}$ & $\begin{array}{l}\text { Reaction } \\
\text { in glia }\end{array}$ \\
\hline \multicolumn{6}{|c|}{ in thousands per $\mathrm{mm}^{3}$ tissue \pm (S.D.) } \\
\hline $\begin{array}{l}1 . \\
2 . \\
3 . \\
4 . \\
5 . \\
6 . \\
7 . \\
8 .\end{array}$ & $\begin{array}{l}\text { Radix ventralis } \\
\text { Nervus hypoglossus } \\
\text { Nervus facialis } \\
\text { Nervus trochlearis } \\
\text { N. oculomotorius (thick fibres only) } \\
\text { N. oculomotorius (common trunk) } \\
\text { Tractus mesencephalici n. trigemini } \\
\text { Nervus trigemini (motor) }\end{array}$ & $\begin{array}{l}1 \cdot 5(1) \\
<1 \\
9(3) \\
6(2) \\
8(2) \\
<1 \\
5(1) \\
9(2)\end{array}$ & $\begin{array}{l}10(4) \\
<1 \\
31(7) \\
41(10) \\
29(7) \\
21(5) \\
52(6) \\
27(6)\end{array}$ & $\begin{array}{l}\text { prominent } \\
\text { prominent } \\
\text { prominent } \\
\text { prominent } \\
\text { prominent } \\
\text { prominent } \\
\text { prominent } \\
\text { prominent }\end{array}$ & $\begin{array}{l}\mathrm{S} \\
\mathrm{S} \\
\mathrm{S} \\
\mathrm{S} \\
\mathrm{M} \\
\mathrm{S}\end{array}$ \\
\hline $\begin{array}{l}9 . \\
10 . \\
11 . \\
12 . \\
13 . \\
14 . \\
15 . \\
16 . \\
17 . \\
18 . \\
19 . \\
20 . \\
21 . \\
22 . \\
23 . \\
24 . \\
25 .\end{array}$ & $\begin{array}{l}\text { Nervus trigemini (common trunk) } \\
\text { Fasciculus gracilis (Goll) } \\
\text { Corpus trapezoides } \\
\text { Fibrae arcuatae ventrales } \\
\text { Fasc. longitudinalis med. (caudal) } \\
\text { Fasc. longitudinalis med. (cranial) } \\
\text { Fasciculus cuneatus (Burdach) } \\
\text { Tractus spinocerebellaris } \\
\text { Corpus restiforme } \\
\text { Tractus pyramidalis (decussatio) } \\
\text { Tractus pyramidalis (medulla) } \\
\text { Tractus pyramidalis (peduncles) } \\
\text { Brachium conjunctivum (proximal) } \\
\text { Brachium conjunctivum (distal) } \\
\text { Thalamus. lamella externa } \\
\text { Tractus pyramidalis (capsula) } \\
\text { Radiatio optica }\end{array}$ & $\begin{array}{r}24(5) \\
10(3) \\
11(3) \\
12(4) \\
10(4) \\
9(4) \\
21(4) \\
8(2) \\
14(4) \\
16(4) \\
18(4) \\
17(5) \\
17(5) \\
15(4) \\
14(2) \\
20(5) \\
21(6)\end{array}$ & $\begin{array}{l}57(11) \\
89(10) \\
30(5) \\
51(8) \\
39(6) \\
40(7) \\
65(6) \\
32(7) \\
42(5) \\
60(8) \\
55(11) \\
48(11) \\
37(10) \\
45(9) \\
59(10) \\
54(10) \\
96(13)\end{array}$ & $\begin{array}{l}\text { mixed } \\
\text { prominent } \\
\text { distinct } \\
\text { distinct-vague } \\
\text { distinct } \\
\text { distinct } \\
\text { distinct } \\
\text { distinct-prominent } \\
\text { distinct } \\
\text { mixed-distinct } \\
\text { mixed-distinct } \\
\text { mixed-distinct } \\
\text { distinct-vague } \\
\text { distinct } \\
\text { distinct } \\
\text { distinct } \\
\text { distinct }\end{array}$ & $\begin{array}{l}M / S \\
W \\
W \\
W / S \\
S \\
M \\
M / S \\
M \\
S \\
S \\
S \\
S \\
M \\
M \\
S \\
M\end{array}$ \\
\hline $\begin{array}{l}26 . \\
27 . \\
28 . \\
29 . \\
30 . \\
31 . \\
32 . \\
33 . \\
34 . \\
35 . \\
36 . \\
37 . \\
38 . \\
39 .\end{array}$ & $\begin{array}{l}\text { Fundus nuclei olivaris inferior } \\
\text { Radix trigemini descendentis } \\
\text { Subst. medull. cerebelli (central) } \\
\text { Subst. medull. cerebelli (subcort.) } \\
\text { Tractus pontocerebellaris } \\
\text { Tractus frontopontinus (pedunculi) } \\
\text { Tractus frontopontinus (capsula) } \\
\text { Commissura anterior } \\
\text { Tractus mammillothalamicus } \\
\text { Corpus callosum (central) } \\
\text { Subst. alba (frontal pole) } \\
\text { Subst. alba (temporal pole) } \\
\text { Subst. alba (parieto-central) } \\
\text { Tractus solitarius }\end{array}$ & $\begin{array}{l}32(4) \\
29(6) \\
27(5) \\
37(7) \\
28(5) \\
36(5) \\
42(7) \\
83(12) \\
31(4) \\
27(3) \\
98(12) \\
79(9) \\
33(6) \\
19(4)\end{array}$ & $\begin{array}{l}71(8) \\
100(23) \\
61(7) \\
68(8) \\
64(8) \\
97(8) \\
91(10) \\
141(11) \\
86(8) \\
85(9) \\
141(10) \\
130(13) \\
114(11) \\
164(26)\end{array}$ & $\begin{array}{l}\text { diffuse } \\
\text { diffuse } \\
\text { mixed } \\
\text { diffuse } \\
\text { diffuse } \\
\text { diffuse } \\
\text { diffuse } \\
\text { diffuse } \\
\text { diffuse } \\
\text { mixed-distinct } \\
\text { diffuse } \\
\text { diffuse } \\
\text { mixed } \\
\text { diffuse }\end{array}$ & $\begin{array}{l}M \\
\mathbf{W} \\
\mathbf{M} \\
\mathbf{M} \\
\mathbf{M} \\
\mathbf{M} \\
\mathbf{M} \\
\mathbf{W} \\
\mathbf{S} / \mathbf{M} \\
\mathbf{M} \\
\mathbf{W} \\
\mathbf{M} \\
\mathbf{W}\end{array}$ \\
\hline
\end{tabular}

- Strong (S), medium (M), weak (W)

1-9. Counts in all of the nerves refer exclusively to the intracerebral portion of the roots.

11. Corpus trapezoides: these axons contained very strong activity of succinic dehydrogenase in the guinea pig; in man, their enzyme activity was distinctly weaker but still confined to the axons.

28,29 . Cerebellum: the cerebellar white matter showed a gradient between the subcortical parts and the central parts, as indicated by the difference between the samples 28 and 29 . Sample 28 is from the vicinity of the dentate nucleus.

35. Corpus callosum: the data in the corpus callosum varied between the rostrum, corpus, and splenium. These portions showed a composition similar to their respective lobes. Sample 35 was derived from the level of the motor region and showed the lowest counts of all the portions of the corpus callosum.

36-38. The number of cells with enzyme activity in the cerebral hemispheres decreased in the region of the U-fibres, although the total count did not change significantly. All the counts were made in the central parts of the lobes. A decrease of the glial enzyme activity in the neighbourhood of grey matter with strong reaction was also found in the perforating fibre bundles in the striatum.

In the pyramidal tracts, the medial longitudinal fascicle, and many other tracts, the definition of the features of the tract was difficult because of the wide-spread fibre spectrum of these tracts. 


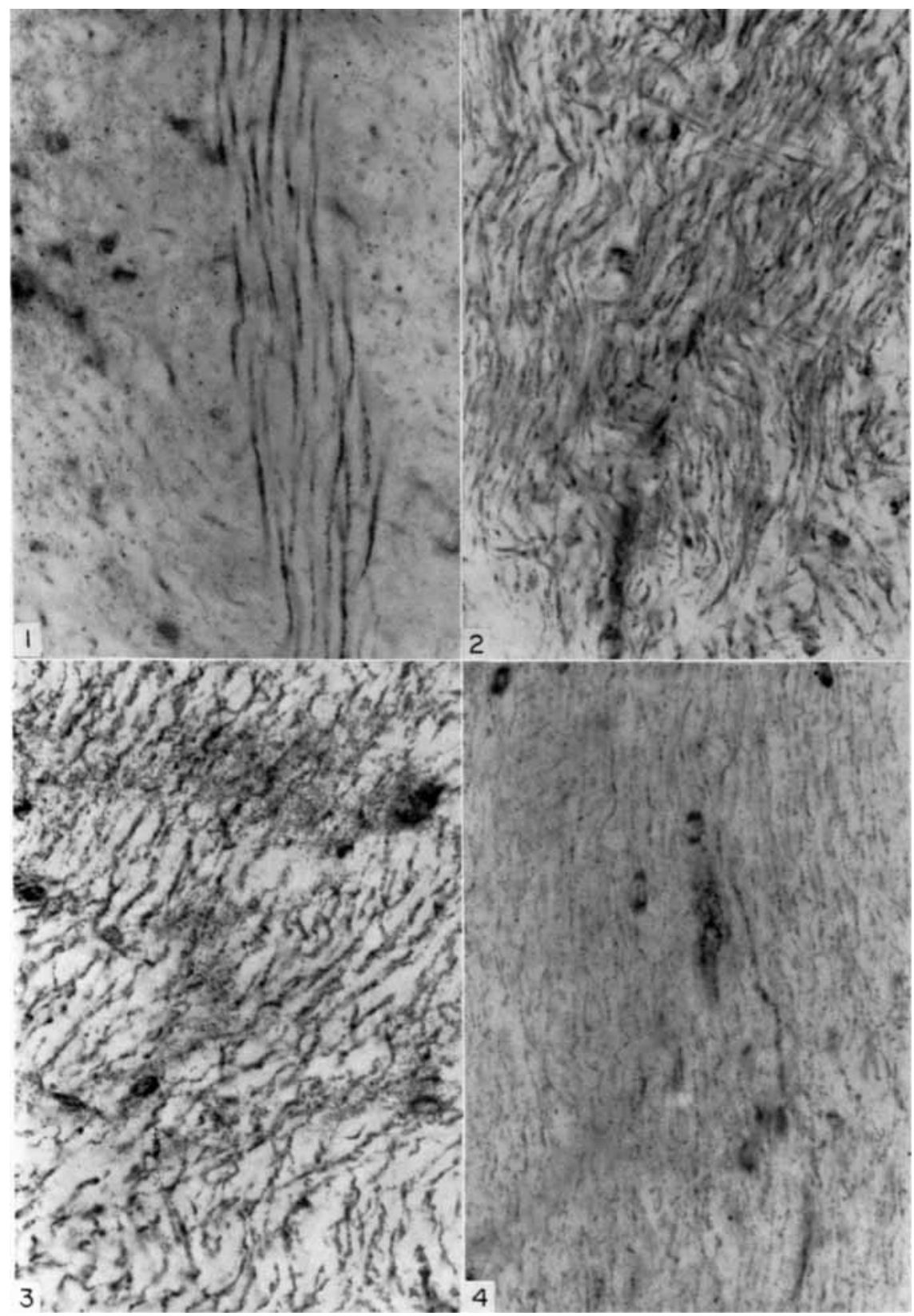

Figs. 1-8, 14, and 15 show fields of exactly equal magnification $(275 \times)$ from sections of equal thickness, printed on equal grade papers. No counterstain was used in any of the illustrations which all show the DPN-diaphorase reaction.

FiG. 1.-Anterior roots in the cervical cord, crossing the ventral tracts; note the absence of glial cells and the strong enzyme activity in the axons.

FIG. 2.-Goll's tract near its nucleus in the upper cervical cord. FIG. 3.-Spinocerebellar tract.

Fig. 4.-Eighth nerve. 


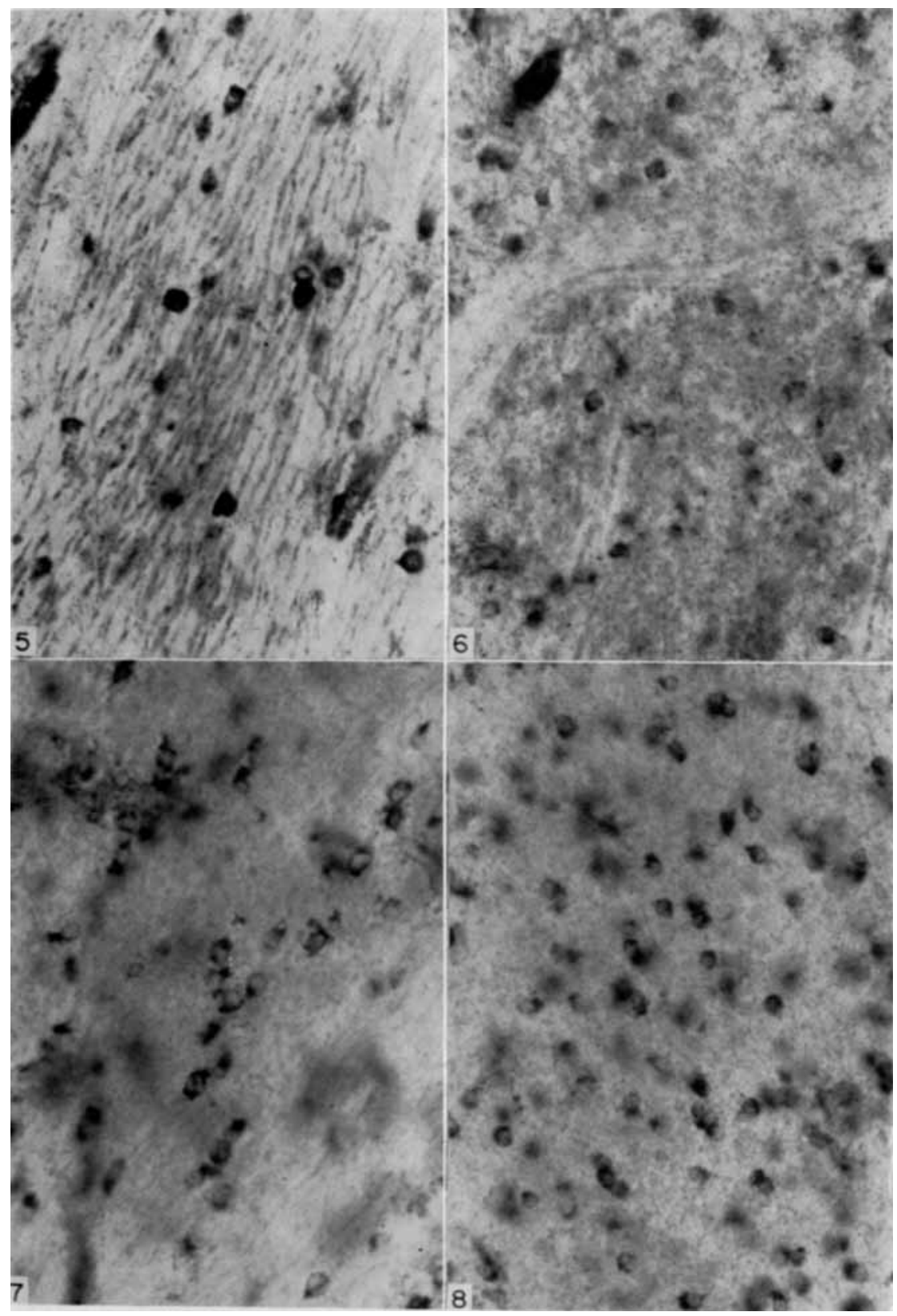

FiGs. 1-8, 14, and 15 show fields of exactly equal magnification (275) from sections of equal thickness, printed on equal grade papers. No counterstain was used in any of the illustrations which all show the DPN-diaphorase reaction.

Fic. 5.-Burdach's tract, adjacent to Goll's tract. Figs. 2, 3, and 5 were taken from the same scction. Note the weaker reaction in the axons and the increase of glia cells with enzyme activity in Fig. 5.

Fic. 6.-Olivary hilus. Absence of glial cells with enzyme activity in the transfixing fibre bundle in the upper part of the picture; this bundle contains fibres with "axonal' activity

Fic. 7.-Pontocerebellar fibres.

(slightly out of focus).

Fir. 8.-Frontal pole, central white matter: note the scarcity of activity outside of glial perikarya, as compared with Figs. 1, 2, and 3. 
exhibited a 'prominent' reaction. These observations emphasize the inverse relationship of the enzyme supply of axons and glial perikarya found throughout this material.

Since these are considerable gradations of oxidative enzyme activity among nuclei of the brain, these might represent another factor modifying the activity in the fibre tracts. The scarcity of cells with enzyme activity among the glial cells in the solitary tract was explained by the fact that the nucleus of the solitary tract is one of those with the weakest activity of oxidative enzymes among all the centres of the brain.

Orientation studies showed that the distribution of succinic dehydrogenase in human white matter resembled that of DPN-diaphorase. The histochemical techniques for cytochrome oxidase did not permit sufficient distinction of cytological details in white matter, but this enzyme is known to have a distribution similar to succinic dehydrogenase. It is likely that the pattern described for DPN-diaphorase is similar to the distribution of other oxidative enzymes.

\section{Histochemical distinction of types of glial cells}

Glial cells with enzyme activity were probably oligodendroglia, as suggested by a comparison of their distribution and number. HORTEGA (1928) distinguished four types of oligodendroglia by the mode of branching of their processes. Cells of type IV resemble Schwann cells, are bipolar or fusiform with few processes, and are attached to, or encompass, medium or thick nerve fibres. This type showed strong enzyme activity in the cytoplasm which was sharply delineated from the encompassed myelin sheath (Figs. 10, 13). Cells of type III are large and have one or two processes which form cytoplasmic rings or spirals around thicker axons. These cells, their processes, and the rings were clearly identified by a strong reaction (Figs. 11, 12, 13) and were seen best in transverse sections of fibre tracts. The reaction in the rings was so strong that rings could be mistaken for glial perikarya and represented a source of error in the counts. Such rings were found only in tracts where the glial perikarya showed strong enzyme activity; if a ring was connected to a perikaryon it was always a perikaryon with strong enzyme activity. Glial cells with strong enzyme activity thus represented mostly oligodendroglia of types III or IV. These cells were distributed characteristically in certain tracts (Table 1) in agreement with HoRTEGA's findings.

Oligodendroglia of types I and II are characterized by many long and delicate processes; these two types were not distinguished from each other histochemically. On the basis of their frequency, cells with medium or weak activity in the perikarya probably represented these types. These cells (Figs. 7,8) predominated in the white matter of the cerebral and cerebellar hemispheres. Their long processes probably contained some of the enzyme activity of the diffuse reaction.

The number of cells without enzyme activity obviously included the population of astrocytes (POPE, 1952, counted 26 per cent astrocytes in the rat's cerebral white matter). The dense marginal layer of astrocytes at the outer surface of the brain almost completely lacks DPN-diaphorase activity but pathological (swollen) astrocytes contain considerably more enzyme activity than normal ones (FRIEDE, 1958).

The problems of the histochemical specificity of certain types of glia were spotlighted by some observations made in fish species (northern pike, Esox lucius; and bowfin, Amia calva). The ependymal cells of lower species have long processes which extend to the surface of the brain where they form small pedicles- 'Tanycyten' (HorstMANN, 1954). These ependymal cells, with their processes and pedicles, contained 
strong activity of DPN-diaphorase (Fig. 9) and were, in certain regions, the tissue element with maximal activity. Some of the functions of glial cells might be performed by this primitive ependyma, since these species had relatively few glia cells: Medulla oblongata (numbers in thousands per $\mathrm{mm}^{3}$ ) total cells, 29(6); cells with enzyme, 12(3). This supports WLassak's (1898) concept, which attributed to these cells some significance for the formation of myelin in lower species.

\section{Myelination of human white matter}

The data reported in this paragraph indicate that the normal enzyme patterns described above determine certain features of myelination. Morphological changes and an increase in the number of glial cells during myelination were described by BoLL (1874), Hortega (1928), Belloni (1930), Morrison (1931), Linell and TOM (1931), Penfield (1924) and AlPers and Haymaker (1934). RobaCK and Scherer (1935) emphasized the increase in the number of glial cells during myelination (Myelinisationsgliose) which was confirmed by counts in the chick embryo by BENSTED et al. (1957). Only DEKABAN (1956) denied an increase in oligodendroglia during myelination (dorsal spinal tracts of the rabbit). HiLd (1957) on the other hand, observed the formation of myelin about axons in tissue cultures without any morphological participation of glial cells. The axoplasm, however, showed an accumulation of mitochondria at the site of formation of myelin.

There is some histochemical evidence of increased activity of the glia during myelination. KOENIG (1958) reported an increased turnover of proteins. The activity of cytochrome oxidase was found to be increased (MARINESCO, 1924). It was reported by FRIEDE (1959a) that in the rat's brain, succinic dehydrogenase increased and decreased in the glia during myelination within a period of about 6-8 days; the onset of this increase preceded the visible formation of myelin. Increased activity was found from the fifth day on in the lateral fibre tracts of the medulla oblongata. The activity increased at about the tenth or twelfth day and reached a maximum at about the fourteenth day in the spinal trigeminal tract, the pyramidal tract, the corpus restiforme, parts of the dorsal and lateral fibre tracts of the cervical spinal cord, the central white matter of the cerebellum and cerebrum, and the fibre stratum of the cornu ammonis. The activity decreased in most fibre systems after the sixteenth day, but it was more persistent in the pyramidal tract, parts of the dorsal tracts of the cervical medulla, the middle cerebellar peduncle, the cornu ammonis, and parts of the cerebral white matter, where activity was found up to the 20th day.

The myelination of the human brain was studied in three regions at eight phases of development. Unfortunately, histochemical material was obtained for only one of these phases. Cell counts were made as described above, the cell numbers were compared with the progress of myelination; densitometric measurements of the staining intensity of the myelin with Sudan black was used as a crude and chemically unspecific parameter of the increase of lipids in the tissue. As a means of control, additional measurements were made in each specimen in regions of grey matter which lacked myelinated fibres, such as the upper layers of the cerebral cortex or the putamen. BraNTE's (1949,) data on lipid content were recalculated for wet weight which approximated the per volume approach in tissue sections. A comparison is made (Fig. 16) of these data with the densitometric measurements; the latter evidently provided a usable parameter of myelination. A comparison of the individual curves reveals that changes 


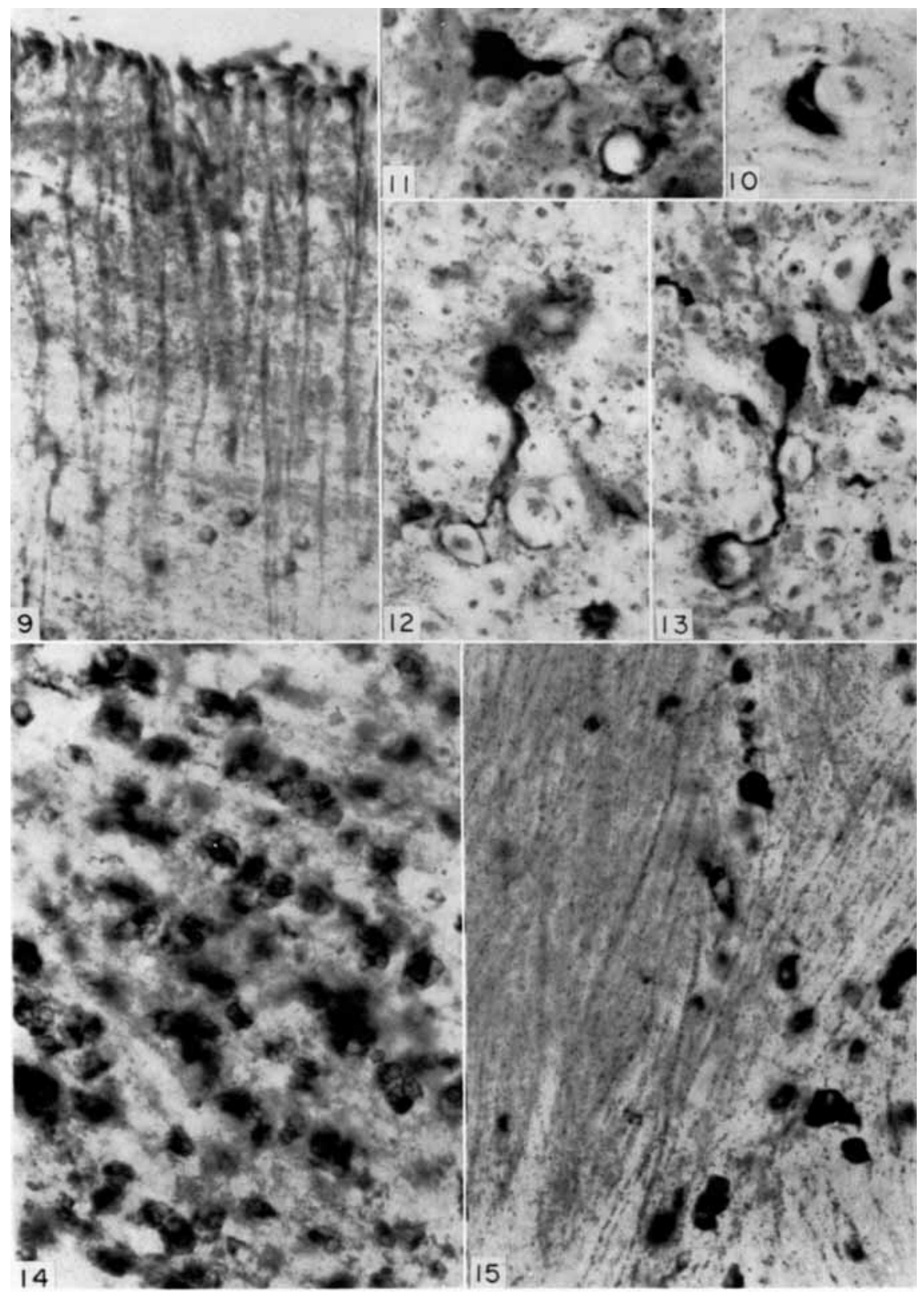

FIGs. 1-8, 14, and 15 show fields of exactly equal magnification (275.) from sections of equal thickness, printed on equal grade papers. No counterstain was used in any of the illustrations which all show the DPN-diaphorase reaction.

FIG. 9.-Processes of ependymal cells with DPN-diaphorase activity in the brain of the bowfin $(275 \times)$.

FIG. 10.-Oligodendroglia, type IV, encompassing a thick fibre; another such cell is seen in the upper part of Fig. $13(440 \times)$.

FIGs. 11-13.--Oligodendroglia, type III, as identified by its typical formation of rings or spirals around thick axons $(440)$.

FIGs. 14 and 15.-Pyramidal tract in the capsula interna: the pictures show homologous regions in the newborn (Fig. 14) and adult (Fig. 15). 

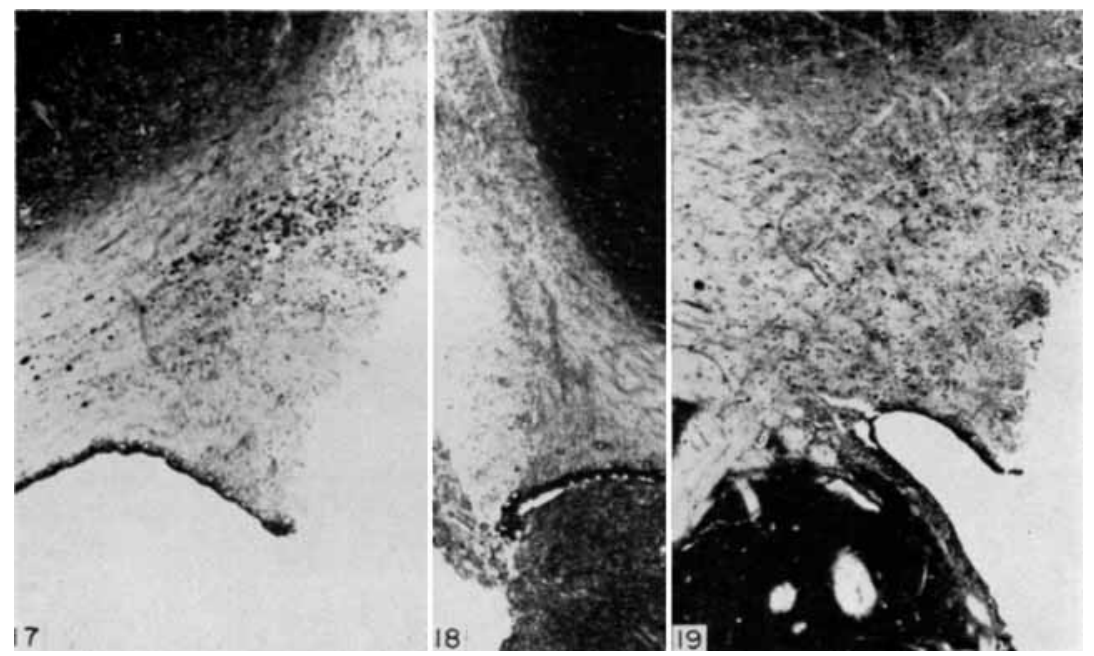

FIGs. 17-19.-Transections of various fibre systems in the cerebral hemispheres of the guinea pig. Note the differences among tracts of the intensity of damming of DPN-diaphorase activity; e.g., in Fig. 17 in the upper and lower part of the picture. Little damming is found in a thin-fibred portion of the corpus callosum (Fig. 18). The dammed fibres represent only a small fraction of the total fibre population (Fig. 19). The dark regions represent the cerebral cortex and the nucl. caudatus (32\%). 
in the lipid content of the white matter of the hemispheres result from a superposition of several, specific changes in individual fibre systems.

Table 2 and Fig. 16 represent the course of myelination in the pyramidal tracts (internal capsule), and in the white matter of the parietal and the temporal lobes. All three regions showed an increase of glial cells which distinctly preceded the formation of lipids (BENSTED et al., 1957). This increase occurred first in the pyramidal tracts,

TABLE 2.-GLIA COUNTS DURING MYELINATION OF HUMAN FIBRE TRACTS

\begin{tabular}{l|c|c|c}
\hline \multicolumn{1}{c|}{ Age } & $\begin{array}{c}\text { Pyramidal tract } \\
\text { (capsula interna) }\end{array}$ & Parietal lobe & Temporal lobe \\
\hline & \multicolumn{3}{|c}{ (Glial cells in thousands per $\mathrm{mm}^{3} \pm$ S.D.) } \\
\hline 6 foetal months & $24 \pm 6$ & $34 \pm 9$ & $79 \pm 12$ \\
8 foetal months & $136 \pm 15$ & $65 \pm 8$ & $64 \pm 8$ \\
Newborn & $155 \pm 10$ & $73 \pm 10$ & $62 \pm 5$ \\
5 months & $124 \pm 10$ & $118 \pm 10$ & $60 \pm 8$ \\
10 months & $93 \pm 10$ & $106 \pm 8$ & $120 \pm 9$ \\
15 months & $81 \pm 9$ & $123 \pm 11$ & $124 \pm 13$ \\
4 years & $67 \pm 7$ & $114 \pm 14$ & $124 \pm 13$ \\
Adult & $54 \pm 10$ & $114 \pm 11$ & $129 \pm 12$ \\
\hline
\end{tabular}

then in the parietal white matter, and last in the temporal white matter, in accordance with the time course of myelination (Fig. 16). The proliferation of cells was accompanied by changes of the nuclei, which led to the differentiation of oligodendroglia (ROBACK and SCHERER, 1935). Following myelination, however, conspicuous differences were found among the regions. In the parietal and temporal lobes, the proliferation of glial cells increased to and maintained the level found in adults. The pyramidal tracts, in contrast, showed a peak in cell count during myelination, followed by a continuous decrease to the low level found in adults. These data provide evidence of the striking differences in the features of myelination among fibre systems.

Histochemical data were available only for the newborn; at this phase, myelination had not started in the parietal and temporal lobes, and there were few cells with enzyme activity. The pyramidal tract was at the peak of myelination and showed many cells with strong DPN-diaphorase activity, exceeding every adult fibre system (Table 3). Figure 14 shows this impressive increase in enzyme activity as compared to the appearance of the homologous region in adults (Fig. 15). In the newborn, no axons could be discerned by enzyme activity, and there was very little 'diffuse' reaction.

The most logical interpretation of these findings was that the glia of the pyramidal tract proliferated because the axons did not have their normal enzyme supply as yet. As the axons matured and attained their normal enzyme content (Fig. 15), the participation of the glia lost significance. The different features of myelination thus seem to reflect the chemical organization of fibre tracts in adults. One would predict that the myelination of other tracts with 'axonal' enzyme supply would follow the pattern of the pyramidal tracts. Orientation counts were made in the intracerebral rootlets of the hypoglossal and (motor) trigeminal nerve of a human fotus (3 1/2 months) at the very outset of myelination. Myelination starts in the motor roots of human cranial nerves at about 14 weeks of age (KEENE and HEWER, 1931) and only a few 

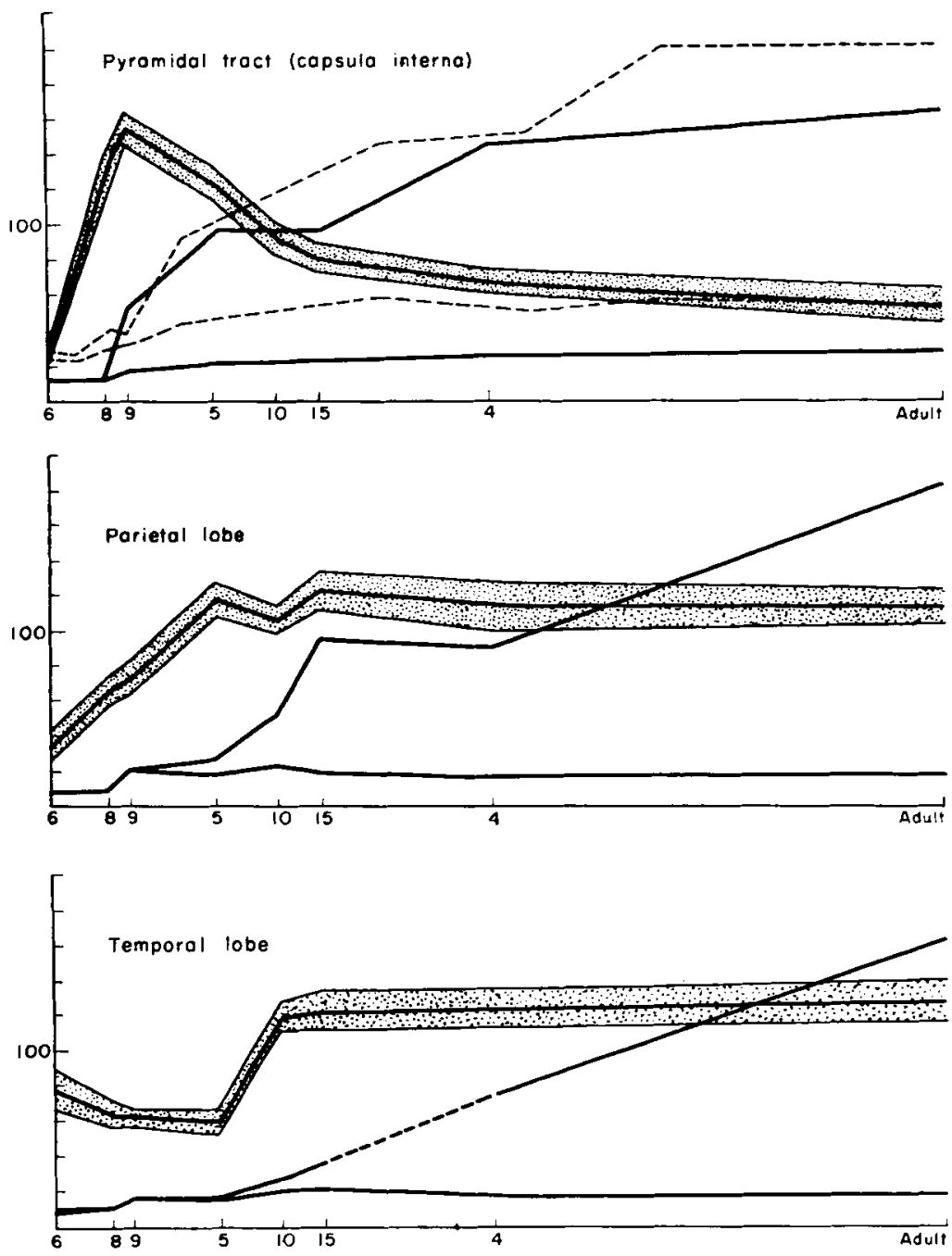

FiG, 16.-Glial cell numbers (Table 3 ) and myelination in the human brain. The dotted curve shows the numbers of glial cells in thousands per $\mathrm{mm}^{3}$ tissue ( \pm S.D.) The solid lines show the densitometric data of myelin formation (upper part of the curve) and of grey matter without myelinated fibres (lower part of the curve). The interrupted lines show BraNTE's (1949) data on total lipids, recalculated for wet weight; BRANTE's curve may be considered as superposition of the three densitometric curves.

The age scale was computed as a logarithmic function from conception (unit one year); this method puts data concerning growth in a more proper relationship.

The relatively high cellularity of the temporal lobe at the sixth month results from the migration of neuroblasts through white matter and has no meaning as to the local cell population. 
fibres with newly formed sheaths were found in the above material. The cell numbers were, in thousands per $\mathrm{mm}^{3}$ : hypoglossal nerve, 136; trigeminal nerve, 148; and pyramidal tracts, 20 . The pyramidal tracts were counted as a control to show that the high numbers of cells in the roots were not due to a higher cellularity of the foetal brain. The myelination of the nerve roots, thus, clearly followed the pattern of the pyramidal tract, which adds further support to the concept that the normal chemical

TABLE 3.-ENZYME CHANGES DURING MYELINATION IN THE HUMAN NEWBORN

\begin{tabular}{|c|c|c|c|c|}
\hline & \multicolumn{2}{|c|}{$\begin{array}{c}\text { Cells with enzymic } \\
\text { activity }\end{array}$} & \multicolumn{2}{|c|}{ Total glial cells } \\
\hline & Newborn & Adult & Newborn & Adult \\
\hline & \multicolumn{4}{|c|}{ (in thousands per $\mathrm{mm}^{3}$ tissue \pm S.D.) } \\
\hline $\begin{array}{l}\text { Pyramidal tracts } \\
\text { (capsula) }\end{array}$ & $108 \pm 11$ & $20 \pm 5$ & $155 \pm 10$ & $54 \pm 10$ \\
\hline Parietal & $13 \pm 3$ & $33 \pm 6$ & $74 \pm 10$ & $114 \pm 11$ \\
\hline Temporal & $17 \pm 3$ & $79 \pm 9$ & $62 \pm 5$ & $130 \pm 13$ \\
\hline
\end{tabular}

organization of the fibres determines the features of myelination. No correction was made for growth in these data, since the increase of glial cells occurred within a short period, during which the growth of the brain was negligible.

\section{The significance of transport of axoplasm in various types of nerve fibres}

Oxidative enzymes, particularly DPN-diaphorase, in the axons derive from the perikaryon and are transported distally in the axon (FrIEDE, 1959b). The gradations of DPN-diaphorase activity in axons implied that transport mechanisms were not of equal significance in all fibre systems. The enzyme supply of the anterior roots, for example, depended almost exclusively on transport in axons, while fibres in the frontal pole relied on the local glia which contained the major share of the total enzyme supply of this region. Transportation might even represent a cause rather than a consequence of the various enzyme patterns in white matter, since the resistance to flow through a tube increases inversely to the square of the diameter.

These conclusions were examined in silver impregnations (HoRTEGA's, silver carbonate technique (1928)) of axons in seven specimens made available by courtesy of Dr. K. SCharenberg; these were biopsy material from surgical resections, diagnostic punctures and chordotomies obtained 1-5 days after surgery. The material was selected to show: (1) a sharply delineated interruption of tracts, (2) a cut longitudinal to the course of the fibres, and (3) no other pathological changes.

Only a fraction of the total number of fibres exhibited a typical damming of axoplasm; the percentages of swollen fibres and of thick fibres were of the same order. The intensity of damming generally decreased with the diameter of the fibres. This relationship was noted by CAJAL (1928): "the extent of retrograde propagation" (now generally recognized as damming, WEISS and HISCOE, 1949) "is proportional to the thickness of the medullated fibre."

Additional experiments in which the white matter in the cerebral hemispheres 
was transected in guinea pigs showed that the fibre swellings seen in silver preparations represented a damming of axoplasm with DPN-diaphorase activity. The animals were killed after 2-4 days. Histochemical preparations showed the typical damming of enzyme activity in the swollen fibre stumps as has been studied in detail in a previous investigation (FRIEDE, 1959c). In accordance with the human material (Table 4) only a fraction of the fibre population showed damming of enzyme activity (Fig. 19). The extent of damming varied considerably among tracts. Some portions of the corpus callosum showed very little damming (Fig. 18), and the damming was confined to certain tracts in other parts of white matter (Fig. 17).

TABLE 4.-FIBRE COUNTS IN SURGICALLY TRANSECTED HUMAN WHITE MATTER

\begin{tabular}{l|c|c|c|c|c}
\hline \multicolumn{1}{c|}{ Type } & $\begin{array}{c}\text { Age } \\
\text { (years) }\end{array}$ & $\begin{array}{c}\text { Survival } \\
\text { (days) }\end{array}$ & $\begin{array}{c}\text { Total } \\
\text { count* }\end{array}$ & $\begin{array}{c}\% \text { Thick } \\
\text { fibres }\end{array}$ & $\begin{array}{c}\% \text { Swollen } \\
\text { fibres }\end{array}$ \\
\hline Puncture hemisphere & 45 & 1 & 143 & 22 & 20 \\
Puncture hemisphere & 39 & 5 & 139 & 42 & 55 \\
Puncture hemisphere & 52 & 2 & 116 & 17 & 29 \\
Puncture hemisphere & 28 & 2 & 106 & 10 & 21 \\
Puncture hemisphere & 64 & 2 & 101 & 14 & 18 \\
Puncture hemisphere & 15 & 4 & 110 & 16 & 56 \\
Chordotomy & 42 & 2 & 476 & 26 & 31 \\
\hline
\end{tabular}

- Counts of the total no. of axons crossing a line of given length, rectangular to the course of the fibres. Counts made about $10 \mathrm{~mm}$ from site of interruption.

$\uparrow$ Percentage of terminal swellings found in a strip of tissue containing the entire length of fibres between the original count and the site of interruption.

\section{DISCUSSION}

The histochemical distribution of DPN-diaphorase in white matter revealed an inverse relationship of the enzyme activity found in axons and in glial cells. Tracts with very prominent reaction in axons showed few, or no, glial cells with enzyme activity. On the other hand, tracts in which axons were not discernible by a positive reaction, showed many glial cells with enzyme activity. The conclusion was drawn from these findings that axons and glia shared the total enzyme activity of a given tract to a widely variable degree among tracts. The tracts with 'axonal' enzyme activity always contained thick fibres, while tracts with 'glial' enzyme activity contained thin fibres. The availability of axoplasm with enzyme activity, thus, was one of the factors determining the activity in glial cells. Axons and glia evidently formed a symbiotic unit; they were "mutually serviceable, and there was established between them something like a symbiosis comparable to the well-known symbiosis of fungi and algae." (CAJAL, 1928, p. 459.)

There was some indication that the pattern of DPN-diaphorase reflected the general pattern of tissue oxidation, since succinic dehydrogenase showed a similar distribution. The patterns of the individual oxidative enzymes in brain tissue generally resemble each other (FRIEDE, 1961).

The number of glial cells per unit volume was found to vary considerably among fibre tracts, but it was rather constant along the course of a given tract. The values obtained by cell counts were of the same order as the data obtained by measuring DNA (Elliott and Heller, 1957; Robins, Smith and EydT, 1956). The data from 
cell counts should be somewhat lower than those from DNA determinations, as endothelial nuclei and contamination by adjacent tissue were eliminated in the counts. Preference was given to cell counts in this investigation as many of the tracts counted were too minute to permit a clean macroscopical dissection.

Most of the cells with DPN-diaphorase activity apparently represent oligodendroglia, while normal astrocytes seem to contain little oxidative enzyme activity (LowRY et al., 1954; POPE et al., 1956; RoBINS and SMITH, 1953). The strong enzyme reaction is in keeping with the appearance of oligodendroglia in the electron microscope (LuSE, 1956; Farquhar and HARTMANN, 1957; DempSey and LuSE, 1958), the high oxidative metabolism of oligodendrogliomas (VICTOR and WOLFF, 1937; ELLIOTT and Heller, 1957) metabolic studies (Pope and Hess, 1957; Hydén and Pigon, 1960; Hess, 1961) and the greater vulnerability of oligodendroglia. Histochemistry even enables one to distinguish certain types of oligodendroglia as described by HoRTEGA (1928); these types are distinguished by gradations of the enzyme reaction in their perikarya.

The normal patterns of enzyme distribution in fibre tracts were related to certain features of myelination. The histochemical patterns of the adult white matter of the parietal and temporal lobes were very similar to each other; both showed predominance of enzyme activity in glial cells. During myelination, both showed an increase in the number of glial cells, which levelled into the permanent adult numbers.

The adult pyramidal tracts and cranial nerve roots were characterized by predominant enzyme reaction in axons and by few glial cells with enzyme activity. During myelination, the number of glial cells in these tracts increased, but, in contrast to the other two regions, decreased after myelination. No enzyme activity was discernible in axons at the peak of myelination. The glial proliferation was considered compensatory and the decrease of glial cells after myelination appeared to be a consequence of the later increase of axon enzyme supply. The type of glial reaction during myelination, therefore, was determined by the type of chemical organization of the adult fibres.

One might speculate on the possibility of myelination without interaction of glia under extreme conditions and the capability of the axon to increase significantly its enzyme activity. HILD (1957) observed, in tissue cultures, increased numbers of mitochondria in the axoplasm at the site of myelination; there was apparently no relation of glial cells to this type of myelination. An increase of the axonal diameter during myelination (SPEIDEL, 1933; DEKABAN, 1956) also indicates some significance of the axon.

DEKABAN (1956) denied an increase in oligodendroglia during myelination; this statement was correct, in as much as the increase of the cell numbers was not simultaneous with, but preceded the formation of myelin, as shown by BENSTED et al. (1957) and in this study. Dekaban's data, as a matter of fact, show the increase of cells exactly where it is expected to be, but only the terminal phase of the increase was counted. It is logical that the multiplication of cells precedes myelination since not the cell division, but the metabolism of the cells thus produced is important for the formation of myelin.

The relative distribution of DPN-diaphorase in axon and glial perikarya suggested that transportation of axoplasma with DPN-diaphorase activity was not of equal significance in all fibre systems. The oxidative enzymes found in the axoplasm 
evidently are derived from the perikaryon and are being carried distally in the axoplasm (for further literature see FrIEDE, 1959b). This conclusion was in keeping with the observation that the extent of damming of axonal flow in transected fibres varied considerably with the fibre's diameter; thin fibres showed very little damming, or none at all. The extent of damming of DPN-diaphorase activity in experimentally transected tracts likewise varied among tracts. If there are differences in transportation and damming in transected fibres, the enzyme changes in the neurons proper might vary as well. KLEIN (1960), accordingly, found an increase of succinic dehydrogenase in spinal ganglion cells following sciatic transection, while this enzyme decreased in motor cells (FrIEDE, 1959b).

In conclusion, axonal and glial cells represent a symbiosis in which the share of metabolic activity of either axons or glia depends on several factors such as the availability of axoplasm, (thickness of fibre), difficulties of axonal enzyme transport, functional activity, and metabolic demands of the sheath (myelination). These findings do not permit the drawing of any conclusions as to the final role played by the glia in the morphological formation of the sheath. Moreover, they apply specifically to central white matter; they should not be applied indiscriminately to Schwann cells in peripheral nerves, since the histochemical architecture of peripheral nerves differs considerably from that of central tracts.

The selection of DPN-diaphorase for this investigation was not determined by speculations as to its possible biochemical significance in lipid metabolism but rather by the fact that this technique was sufficiently sensitive and reliable to demonstrate consistently minute gradations of enzyme activity in white matter. It is known, nevertheless, that the biosynthesis of phosphatides requires the presence of tissue oxidation and that inhibition of the latter inhibits the formation of phosphatides (Artom and Cornatzer, 1951; Taurog, Chaikoff and Perlman, 1942; Schachner, Fries and ChalkofF, 1942). Changes in the activity of oxidative enzymes, thus, may indirectly indicate changes of more specific phases of lipid biosynthesis. The persistence of high glial counts in certain fibre systems after completion of myelination agrees with the persistent high rate of turnover of certain lipids during and after myelination (WAelsCh, SPERRY and StOYANOFF, 1940).

\section{SUMMARY}

A systematic study of the histochemical distribution of DPN-diaphorase in human white matter showed an inverse relationship of the enzyme activity in axons and in glial cells. A strong reaction in axons was accompanied by few glial cells with enzyme activity; tracts in which axons could not be discerned by a positive reaction, contained many glial perikarya with enzyme activity. One of the factors determining this inverse relationship was the thickness of the fibres (availability of axoplasm with enzyme): thick fibres always showed an 'axonal' enzyme supply and thin fibres a 'glial' enzyme supply.

The glial perikarya with enzyme activity represented mostly oligodendroglia. Certain types of oligodendroglia could be distinguished histochemically by gradients of the reaction in the perikarya.

The normal histochemical organization of fibre tracts was found to determine certain features of myelination. Preceding the formation of myelin, there was a sharp increase in the number of glial cells and an increase of enzyme activity in them. The 
population of glia after completion of myelination differed among tracts; high glial numbers were maintained in tracts with 'glial' enzyme supply, while the number of cells decreased in tracts with 'axonal' enzyme supply.

Another factor influencing the histochemical architecture of a fibre tract was the increasing difficulty of axonal flow and transport of enzymes in thinner fibres. This was demonstrated by differences in the intensities of damming of axonal flow and transport of enzyme activity after transection of mixed fibre populations.

The central nerve fibres represent a complex symbiosis of axons and glial cells, in which the metabolic share of each depends on several factors, such as availability of axoplasm (diameter of the axon), intensity of axonal flow, functional activity, and metabolic demands of the sheath (myelination).

Acknowledgements - The author is indebted to Mrs. LA Dona FLEMING for her meticulous assistance in preparing this material.

\section{REFERENCES}

AIPERS J. and HAYMAKer W. (1934) Brain, 57, 195.

Artom C. and Cornatzer W. E. (1951) Fed. Proc. 7, 145.

Belloni G. B. (1930) Rev. Parhol. 35, 175.

Bensted J. P. M., Dobling T., Morgan R. S., Reid R. J. and Playling-Wright G. (1957) J. Embyrol. $5,428$.

BOLl F. (1874) Arch. Psychiair. 4, 1.

Brante G. (1949) Acta physiol. scond. 18, Suppl. 63, 124.

Cajal S. R. (1928) Degeneration and Regeneration of the Nervous System. Milford, London.

Dekaban A. (1956) Anat. Rec. 126, 111.

DEMPSEY E. W. and LUSE S. A. (1958) In Symposium on the Biology of Neuroglia. (Edited by WINDLE W. F.) p. 99. Thomas, Springfield, Illinois.

El.Liott K. A. C. and Heller I. H. (1957) In Metabolism of the Nervous System. (Edited by RICHTER D.) p. 286. Pergamon, New York.

Farber E., Sternberg W. H. and Dunlap C. E. (1956) J. Histochem. Cytochem. 4, 254.

Farquhar M. G. and Hartmann J. F. (1957) J. Neuropath. 16, 18.

Feldberg W. and VoGt M. (1948) J. Physiol. 107, 273.

FRIEDE R. L. (1958) Virchows Arch. 332, 216.

Friede R. L. (1959a) J. Neurochem. 4, 101.

FRIEDE R. L. (1959b) Exp. Neurol. 1, 441.

FRIEDE R. L. (1961) Histochemical Atlas of Tissue Oxidation in the Brain Stem of the Cat. Karger, New York.

Hess H. H. (1961) In Proc. IVth Int. Neurochem. Symp. (Edited by Kety S. S.) (In press) Pergamon. London.

HiLd W. (1957) Z. Zellforsch. 46, 71.

HORSTMANN E. (1954) Z. Zellforsch. 39, 588.

Hortega R. (1928) Mem. Soc. esp. Hist. Nat. Vol. 14.

HYdéN H. and PIGON A. (1960) J. Neurochem. 6, 57.

Keene M. F. L. and Hewer E. E. (1931)J. Anat., Lond. 66, part 1.

KleIN H. (1960) Arch. Psychiat. Z. Neurol. 201, 81.

Koenig H. (1958) J. Histochem. Cytochem. 6, 93.

Linell. E. A. and Tom M. I. (1931) Anat. Rec. 48, Suppl. 27.

Lowry D. H., Roberts N. R., Leiner K. Y., WU M. L., FarR A. L. and Albers R. W. (1954) J. biol. Chem. 207, 39.

Lloyd D. P. and Chang H. T. (1948) J. Neurophysiol. 11, 199.

LuSE S. A. (1956) J. biophys. biochem. Cytol. 2, 531.

Marinesco G. (1924) Ann. anat. path. 1, 121.

MORRISON L. R. (1931) Trans. Amer. neurol. Ass. 57, 444.

Pearse A. G. E. (1960) Histochemistry. Little Brown, Boston. 
Penfield W. (1924) Brain 47, 430.

POPE A. (1952) J. Neurophysiol. 15, 115.

Pope A. and Hess H. (1957) In Metabolism of the Nervous System. (Edited by RJCHTER D.) p. 72. Pergamon, London.

Pope A., Hess H. H., Ware J. R. and Thomson R. H. (1956) J. Neurophysiol. 19, 259.

Rorack H. N. and Scherer H. J. (1935) Virchows Arch. 294, 365.

Robins E. and Smith D. E. (1953) Res. Publ. Ass. nerv. ment. Dis. 32, 305.

Robins E., Sмith D. E. and Eydt M. (1956) J. Neurochem. 1, 54.

SAMORAJSKI T. (1960) J. Neurochem. 5, 349.

Scarpeli D. G., Hess R. and Pearse A. G. E. (1958) J. Histochem. Cytochem. 6, 369.

Schachner H., Fries B. A. and Chaikoff I. L. (1942) J. biol. Chem. 146, 95.

Shimizu N. (1950) J. comp. Neurol. 93, 201.

SPEIDEL C. C. (1932) J. exp. Zool. 61, 279.

Speidel C. C. (1933) Amer. J. Anat. 52, 1.

Taurog A., Chaikoff I. L. and Perlman I. (1942) J. biol. Chem. 145, 281.

VICTOR J. and Wolff A. (1937) Res. Publ. Ass. nerv. ment. Dis. 16, 44.

Waelsch H., Sperry W. M. and Stoyanoff V. A. (1940) J. biol. Chem. 135, 291.

Weiss P. and Hiscoe H. B. (1949) J. exp. Zool. 107, 315.

Wlassak R. (1898) Arch. EntwMech. Org. 6, 453. 